\title{
Mechanism of Osmium(VIII) Catalysed Oxidation of L-Arginine by Periodate in Alkaline Medium - A Kinetic Study
}

\author{
G. SRIDEVI ${ }^{1}$, N. ANNAPURNA ${ }^{2}$ and P. VANI ${ }^{3 *}$ \\ ${ }^{1,3}$ Department of Inorganic and Analytical Chemistry, Andhra University, \\ Visakhapatnam-530 003, A.P, India \\ ${ }^{2}$ Department of Engineering Chemistry, AUCE(A), Andhra University, \\ Visakhapatnam-530 003, A.P, India \\ vani_chem@rediffmail.com
}

Received 11 February 2015 / Accepted 4 March 2015

\begin{abstract}
The kinetics of the osmium(VIII) catalyzed oxidation of $L$-arginine by periodate has been studied spectrophotometrically in alkaline medium at $280 \mathrm{~nm}$. The reaction is first order with respect to [catalyst]. The reaction showed second order dependence on [periodate], fractional order dependence on [alkali] and is independent of substrate. The oxidation product of the reaction was found to be $\alpha$ - keto acid. A plausible mechanism has been proposed. The energy of activation, $\mathrm{E}_{\mathrm{a}}$ and entropy of activation, $\Delta \mathrm{S}^{\#}$ were computed and are found to be $53.00 \pm 1.78 \mathrm{~kJ} \mathrm{~mol}^{-1}$ and $-46.30 \pm$ $5.34 \mathrm{JK}^{-1} \mathrm{~mol}^{-1}$ respectively.
\end{abstract}

Keywords: Oxidation of $L$-arginine, Periodate, Osmium(VIII)

\section{Introduction}

$L$-Arginine is one of the essential amino acid and is an important constituent of proteins. Since it is an essential amino acid it can not be synthesized by human body. The kinetics and mechanism of oxidation of arginine were studied previously using various oxidants ${ }^{1-14}$. In continuation of our studies on the oxidation of $L$-arginine ${ }^{15-16}$, we now report the mechanism of its oxidation in alkaline medium by periodate in presence of osmium(VIII). Osmium(VIII) acts as a catalyst in several redox reactions in alkaline solution. The mechanism of catalysis is quite complicated due to the formation of different intermediate complexes, free radicals and different oxidation states of osmium.

The uncatalysed oxidation of arginine by alkaline periodate ${ }^{16}$ was studied at $323 \mathrm{~K}$. Since there is no direct reaction between $L$-arginine and periodate at $303 \mathrm{~K}$ and since osmium(VIII) was found to catalyse the reaction considerably, we have undertaken a detailed kinetic and mechanistic study of the title reaction in $0.4 \mathrm{~mol} \mathrm{dm}^{-3}$ alkaline medium. 
The standard solution of $L$-arginine was prepared by using double distilled water. The other chemicals used were periodate, sodium hydroxide, osmium(VIII) and $\mathrm{NaClO}_{4}$. All chemicals used were of AR grade. A $0.01 \mathrm{~mol} \mathrm{dm}^{-3}$ solution of osmium(VIII) is prepared in $0.25 \mathrm{~mol} \mathrm{dm}^{-3}$ sodium hydroxide from osmium tetraoxide. Its strength is determined by taking an aliquot volume of the solution into $0.5 \mathrm{~mol} \mathrm{dm}^{-3}$ hydrochloric acid, adding $10 \mathrm{~mL}$ of $10 \% \mathrm{KI}$ and titrating the liberated iodine with sodium thiosulfate solution using starch as indicator. Solutions of desired concentration are prepared from this stock by suitable dilution. The reaction was initiated by mixing a calculated amount of periodate to a mixture of $L$-arginine, sodium hydroxide, osmium(VIII) and sodium perchlorate at a constant temperature of $30 \pm 0.1{ }^{\circ} \mathrm{C}$. The progress of the reaction was followed by measuring the absorbance of periodate at $280 \mathrm{~nm}$ using Milton Roy $1201 \mathrm{UV}$-Visible spectrophotometer with $1 \mathrm{~cm}$ glass cells. The temperature is kept constant using a SISKIN JULABO V constant temperature liquid circulatory bath. Plots of 1 /absorbance versus time are found to be linear even beyond $85 \%$ completion of the reaction indicating that the reaction is second order with respect to [periodate].

\section{Results and Discussion}

Known amounts of $L$-arginine were allowed to react completely with a known excess of periodate in presence of osmium(VIII) at $30{ }^{\circ} \mathrm{C}$ in $0.4 \mathrm{~mol} \mathrm{dm}^{-3} \mathrm{NaOH}$ at an ionic strength of $0.5 \mathrm{~mol} \mathrm{dm}^{-3}$. The remaining periodate was then analyzed spectrophotometrically. As per these results the stoichiometry was found to correspond to the equation.

The test for free radicals was carried out by taking $L$-arginine, $\mathrm{NaOH}$, Osmium(VIII) in a thumberg tube and acrylonitrile and periodate in a bent tube. After evacuating the system the solutions were mixed by tilting the tube. The reaction mixture was kept aside and even after $24 \mathrm{~h}$ no precipitate was observed, indicating the absence of free radicals. The main oxidation product was identified by $\mathrm{FeCl}_{3}$ solution that gave a reddish brown precipitate indicating the presence of a keto acid. Similarly ammonia was identified by Nessler's reagent.

The [arginine] was varied in the range of $2.0-7.0 \times 10^{-2} \mathrm{~mol} \mathrm{dm}^{-3}$ at $30^{\circ} \mathrm{C}$ by keeping all other reactant concentrations and conditions constant. The rate constant values remain constant with increase in [arginine] (Table 1) and the order with respect to [arginine] was found to be zero.

Table 1. Effect of [periodate], [Arg], $\left[\mathrm{OH}^{-}\right],[\mathrm{Os}(\mathrm{VIII})$ and ionic strength, on the pseudo second order rate constant $\left(\mathrm{k}^{\prime \prime}\right)$, at $30 \pm 0.1{ }^{\circ} \mathrm{C}$

\begin{tabular}{cccccc}
\hline $\begin{array}{c}\text { periodate] } \times 10^{3} \\
\mathrm{~mol} \mathrm{dm}^{-3}\end{array}$ & $\begin{array}{c}\text { [Arg] } \times 10^{2} \\
\mathrm{~mol} \mathrm{dm}^{-3}\end{array}$ & $\begin{array}{c}\mathrm{Os}(\mathrm{VIII}) \times 10^{5} \\
\mathrm{~mol} \mathrm{dm}\end{array}$ & $\begin{array}{c}{\left[\mathrm{OH}^{-}\right]} \\
\mathrm{mol} \mathrm{dm}^{-3}\end{array}$ & $\begin{array}{c}\mu \\
\mathrm{mol} \mathrm{dm}^{-3}\end{array}$ & $\begin{array}{c}\mathrm{k} \times 10^{6}, \mathrm{~mol}^{-1} \\
\mathrm{dm}^{3} \mathrm{~s}^{-1}\end{array}$ \\
\hline 0.1 & 4.0 & 1.0 & 0.4 & 0.5 & 46.3 \\
0.5 & 4.0 & 1.0 & 0.4 & 0.5 & 46.2 \\
1.0 & 4.0 & 1.0 & 0.4 & 0.5 & 46.9 \\
1.5 & 4.0 & 1.0 & 0.4 & 0.5 & 46.8 \\
2.0 & 4.0 & 1.0 & 0.4 & 0.5 & 46.5 \\
2.5 & 4.0 & 1.0 & 0.4 & 0.5 & 46.7 \\
1.0 & 2.0 & 1.0 & 0.4 & 0.5 & 46.8 \\
1.0 & 3.0 & 1.0 & 0.4 & 0.5 & 46.5 \\
1.0 & 4.0 & 1.0 & 0.4 & 0.5 & 46.9 \\
1.0 & 5.0 & 1.0 & 0.4 & 0.5 & 46.6 \\
1.0 & 6.0 & 1.0 & 0.4 & 0.5 & 46.4 \\
1.0 & 7.0 & 1.0 & 0.4 & 0.5 & 46.9 \\
1.0 & 4.0 & 0.5 & 0.4 & 0.5 & 23.4 \\
\hline
\end{tabular}




\begin{tabular}{cccccc}
\hline 1.0 & 4.0 & 1.0 & 0.4 & 0.5 & 46.9 \\
1.0 & 4.0 & 1.5 & 0.4 & 0.5 & 66.5 \\
1.0 & 4.0 & 2.0 & 0.4 & 0.5 & 89.9 \\
1.0 & 4.0 & 2.5 & 0.4 & 0.5 & 113.4 \\
1.0 & 4.0 & 3.0 & 0.4 & 0.5 & 136.9 \\
1.0 & 4.0 & 1.0 & 0.20 & 0.8 & 35.2 \\
1.0 & 4.0 & 1.0 & 0.25 & 0.8 & 37.1 \\
1.0 & 4.0 & 1.0 & 0.30 & 0.8 & 39.1 \\
1.0 & 4.0 & 1.0 & 0.35 & 0.8 & 43.0 \\
1.0 & 4.0 & 1.0 & 0.40 & 0.8 & 46.9 \\
1.0 & 4.0 & 1.0 & 0.50 & 0.8 & 50.8 \\
1.0 & 4.0 & 1.0 & 0.60 & 0.8 & 54.7 \\
\hline
\end{tabular}

The effect of alkali on the rate of the reaction was studied at constant concentrations of arginine and periodate and at a constant ionic strength of $0.8 \mathrm{~mol} \mathrm{dm}^{-3}$ at $30{ }^{\circ} \mathrm{C}$. The rate constants obtained were found to increase with the increase in [alkali] (Table 1). Further, the plot $\log \mathrm{k}^{\prime \prime}$ versus $\log \left[\mathrm{OH}^{-}\right]$(Figure 1) is found to be a straight line with a slope of 0.43 indicating fractional order dependence on $\left[\mathrm{OH}^{-}\right]$.

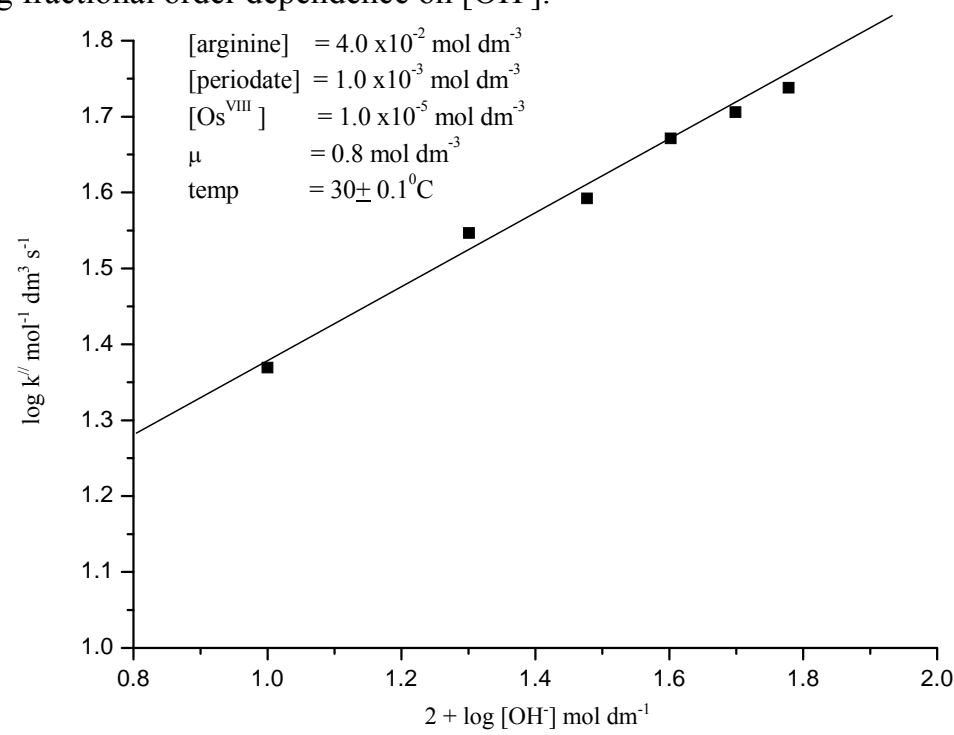

Figure 1. Plot of $\log \mathrm{k}^{\prime \prime}$ versus $\log \left[\mathrm{OH}^{-}\right]$(order with respect to $\left[\mathrm{OH}^{-}\right]$)

The effect of [periodate] was studied by varying the [periodate] in the reaction medium from $0.1-2.5 \times 10^{-3} \mathrm{~mol} \mathrm{dm}^{-3}$ at constant arginine, alkali and osmium(VIII) concentrations. The rate constants obtained were presented in Table 1 .

The catalyst, [osmium(VIII)] was varied in the range $0.5-3.0 \times 10^{-5} \mathrm{~mol} \mathrm{dm}^{-3}$ keeping the concentration of all other reactants constant. When the pseudo second order rate constants, $\mathrm{k}^{\prime \prime}$ obtained at different [Osmium(VIII)] are plotted against [osmium(VIII)], a straight line passing through origin is noticed indicating unit order dependence on [osmium(VIII)].

The effect of ionic strength was studied by varying the $\left[\mathrm{NaClO}_{4}\right]$ in the reaction medium from $0.5-1.0 \mathrm{~mol} \mathrm{dm}^{-3}$ at constant [periodate], [arginine], [alkali] and [osmium(VIII)]. The rate constants were found to remain constant (Table 1) indicating negligible effect of ionic strength on reaction rate. 
The effect of temperature on the rate is studied by carrying out the reaction at $25,30,35$ and $40{ }^{\circ} \mathrm{C}$ and the rate constants thus obtained were found to be35.2, 46.9, 66.9 and 93.9 $\mathrm{mol}^{-1} \mathrm{dm}^{3} \mathrm{~s}^{-1}$ respectively. The plot of $\log \mathrm{k}^{\prime \prime}$ against $1 / \mathrm{T}$ is linear indicating that the reaction obeys Arrhenius temperature dependence. The energy of activation $\mathrm{E}_{\mathrm{a}}$ and the entropy of activation $\Delta \mathrm{S}^{\#}$ are calculated using linear least squares method and found to be $53.04 \pm 1.78$ $\mathrm{kJ} \mathrm{mol}^{-1}$ and $-46.342 \pm 5.34 \mathrm{JK}^{-1} \mathrm{~mol}^{-1}$ respectively.

Under the present experimental conditions, at a $\left[\mathrm{OH}^{-}\right]=0.4 \mathrm{~mol} \mathrm{dm}^{-3}$ arginine exists in the form of anionic species, $\mathrm{Arg}^{-}\left(\mathrm{NH}=\mathrm{C}\left(\mathrm{NH}_{2}\right)-\mathrm{NH}-\left(\mathrm{CH}_{2}\right)_{3}-\mathrm{CH}\left(\mathrm{NH}_{2}\right)-\mathrm{COOH}\right)$, Since the rate of the reaction is independent of arginine concentration, the observed increase in rate with increase in alkali concentration is attributed to change in concentration of active periodate species according to the equation.

$$
\mathrm{H}_{3} \mathrm{IO}_{6}^{2-}+\mathrm{OH}^{-} \stackrel{\mathrm{K}_{1}}{\rightleftharpoons} \mathrm{H}_{2} \mathrm{IO}_{6}^{3-}+\mathrm{H}_{2} \mathrm{O} \text {. }
$$

In strongly basic medium the active form of osmium(VIII) can be considered as $\left[\mathrm{OsO}_{4}(\mathrm{OH})_{2}\right]^{2-}$. Based on these observations the following mechanism is proposed for the osmium(VIII) catalysed oxidation of arginine by periodate.

\section{Mechanism}

$$
\left[\mathrm{OsO}_{4}(\mathrm{OH})_{2}\right]^{2-}+\mathrm{Arg}^{-} \stackrel{\text { fast }}{\longrightarrow}\left[\mathrm{OsO}_{4}(\mathrm{OH})_{2}\right]^{4^{-}}+\mathrm{Arg} \cdot \text { keto acid }
$$

Formation of osmium(VI) as intermediate in a fast step was also proposed earlier by Dikshitulu et $a l .{ }^{17}$ in the osmium(VIII) catalysed oxidation of selenium(IV) by periodate in alkaline medium.

$$
\begin{aligned}
& \mathrm{H}_{3} \mathrm{IO}_{6}^{2-}+\mathrm{OH}^{-} \stackrel{\mathrm{K}_{1}}{\rightleftharpoons} \mathrm{H}_{2} \mathrm{IO}_{6}^{3-}+\mathrm{H}_{2} \mathrm{O} \\
& {\left[\mathrm{OsO}_{4}(\mathrm{OH})_{2}\right]^{4^{-}}+\mathrm{H}_{2} \mathrm{IO}_{6}^{3-} \stackrel{\mathrm{K}_{2}}{\rightleftharpoons} \mathrm{x}_{1} \quad \text { fast }} \\
& \mathrm{X}_{1}+\mathrm{H}_{2} \mathrm{IO}_{6}^{3-} \stackrel{\mathrm{K}_{3}}{\rightleftharpoons} \mathrm{X}_{2} \stackrel{\text { fast }}{\rightleftharpoons} \\
& \mathrm{X}_{2} \underset{\text { slow }}{\stackrel{\mathrm{k}}{\longrightarrow}}\left[\mathrm{OsO}_{4}(\mathrm{OH})_{2}\right]^{2-}+2 \mathrm{I}^{\mathrm{VI}} \\
& \mathrm{Arg}^{-}+2 \mathrm{I}^{\mathrm{VI}} \stackrel{\text { fast }}{\longrightarrow} \mathrm{Arg} \cdot \text { keto acid }+2 \mathrm{I}^{\mathrm{V}}
\end{aligned}
$$

This mechanism leads to the rate equation,

$$
\text { Rate }=\frac{-\mathrm{d}[\text { periodat } \mathrm{e}]}{\mathrm{dt}}=k\left[X_{2}\right]
$$

Substituting for $\left[\mathrm{X}_{2}\right]$ from equation(3) in equation (6) gives

$$
\begin{gathered}
=\mathrm{k} \mathrm{K}_{3}\left[\mathrm{X}_{1}\right]\left[\mathrm{H}_{2} \mathrm{IO}_{6}^{3-}\right] \mathrm{e} \\
\mathrm{k} \mathrm{K}_{2} \mathrm{~K}_{3}\left[\mathrm{O}_{\mathrm{S}} \mathrm{O}_{4}(\mathrm{OH})_{2}^{4-}\right]\left[\mathrm{H}_{2} \mathrm{IO}_{6}^{3-}\right]_{e}^{2} \\
{[\text { per }]_{\mathrm{t}}=\left[\mathrm{H}_{3} \mathrm{IO}_{6}^{2-}\right]_{\mathrm{e}}+\left[\mathrm{H}_{2} \mathrm{IO}_{6}^{3-}\right]_{\mathrm{e}}}
\end{gathered}
$$




$$
=\frac{\left[\mathrm{H}_{2} \mathrm{IO}_{6}^{3-}\right]+\mathrm{K}_{1}\left[\mathrm{OH}^{-}\right]\left[\mathrm{H}_{2} \mathrm{IO}_{6}^{3-}\right]}{\mathrm{K}_{1}\left[\mathrm{OH}^{-}\right]}
$$

$$
\text { Therefore, }\left[\mathrm{H}_{2} \mathrm{IO}_{6}^{3-}\right]_{\mathrm{e}}=\frac{\mathrm{K}_{1}\left[\mathrm{OH}^{-}\right][\text {per }]_{\mathrm{t}}}{1+\mathrm{K}_{1}\left[\mathrm{OH}^{-}\right]}
$$

Substituting for $\left[\mathrm{H}_{2} \mathrm{IO}_{6}{ }^{3-}\right]$ from equation (10) in equation (8) leads to

$$
\text { Rate }=\frac{\mathrm{k} \mathrm{K}_{1}^{2} \mathrm{~K}_{2} \mathrm{~K}_{3}\left[\mathrm{OsO} 4(\mathrm{OH})_{2}^{2-}\right]\left[\mathrm{OH}^{-}\right]^{2}[\mathrm{per}]_{\mathrm{t}}^{2}}{1+\mathrm{K}_{1}^{2}\left[\mathrm{OH}^{-}\right]^{2}}
$$

The above equation explains second order dependence on [periodate], unit order with respect to [osmium(VIII)] and fractional order with respect to [alkali].

Since, $\left[\mathrm{OsO}_{4}(\mathrm{OH})_{2}{ }^{2-}\right]=\left[\mathrm{Os}^{\mathrm{VIII}}\right]_{\mathrm{t}}$, equation (11) may be written as

$$
\frac{\text { Rate }}{[\text { per }]_{\mathrm{t}}^{2}}=\mathrm{k}^{\prime \prime}=\frac{\mathrm{k} \mathrm{K}_{1}^{2} \mathrm{~K}_{2} \mathrm{~K}_{3}\left[\mathrm{Os}^{\mathrm{VIII}}\right]_{\mathrm{t}}\left[\mathrm{OH}^{-}\right]^{2}}{1+\mathrm{K}_{1}^{2}\left[\mathrm{OH}^{-}\right]^{2}}
$$

Taking reciprocals on both sides of equation (12) gives

$$
\frac{1}{k}^{\prime \prime}=\frac{1}{\mathrm{k} \mathrm{K}_{1}^{2} \mathrm{~K}_{2} \mathrm{~K}_{3}\left[\mathrm{Os}^{\mathrm{VIII}}\right]_{\mathrm{t}}\left[\mathrm{OH}^{-}\right]^{2}}+\frac{1}{\mathrm{k} \mathrm{K}_{2} \mathrm{~K}_{3}\left[\mathrm{Os}^{\mathrm{VIII}}\right]_{\mathrm{t}}}
$$

Equation(13) predicts the plot of $1 / \mathrm{k}^{\prime \prime}$ versus $1 /\left[\mathrm{OH}^{-}\right]^{2}$ should be a straight line with a positive intercept on $Y$-axis. Similar plot (Figure 2) was obtained experimentally at higher $\left[\mathrm{OH}^{-}\right]$, but at lower $\left[\mathrm{OH}^{-}\right]$the deviation of points from the straight line indicates that $\mathrm{H}_{2} \mathrm{IO}_{6}{ }^{3-}$ may be getting converted to $\left[\mathrm{H}_{3} \mathrm{IO}_{6}\right]^{2-}$, thus supporting the proposed mechanism.

Further, it is also possible to calculate the value of $\mathrm{K}_{1}$ from the ratio of intercept to slope of the plot of $1 / \mathrm{k}^{\prime \prime}$ versus $1 /\left[\mathrm{OH}^{-}\right]^{2}$ and it was found to be $4.05 \mathrm{~mol}^{-1} \mathrm{dm}^{3}$. This value is found to be reasonably in good agreement with a value of $3.10 \mathrm{~mol}^{-1} \mathrm{dm}^{3}$ reported by Nandibewoor et al. ${ }^{18}$ in the ruthenium(III) / osmium(VIII) catalysed oxidation of allyl alcohol by periodate in aqueous alkaline medium, which further substantiates the proposed mechanism.

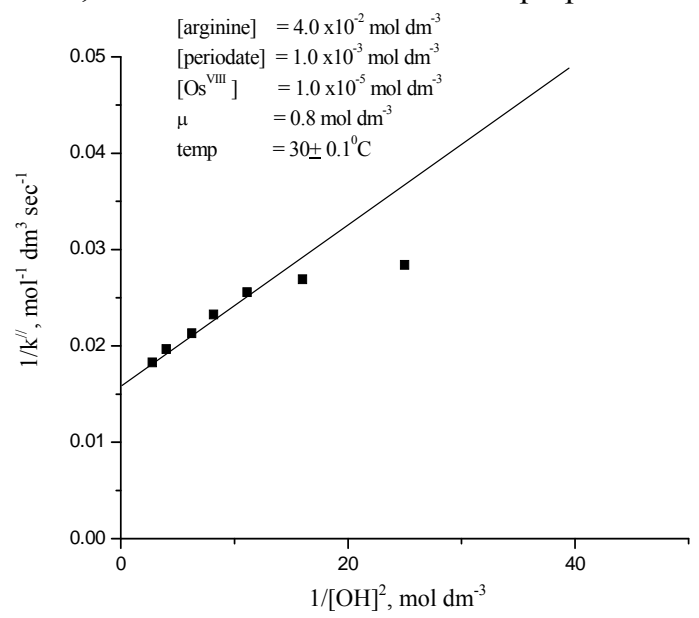

Figure 2. Plot of $1 / \mathrm{k}^{\prime \prime}$ versus $1 /[\mathrm{OH}]^{2}$ 
The following arguments are in support of the proposed intimate mechanism.

- Osmium(VIII) reacts with arginine to form osmium(VI) and 5-guanidino-2-oxo pentanoic acid (arginine keto acid) in a fast step.

- $\mathrm{H}_{3} \mathrm{IO}_{6}{ }^{2-}$ is known to undergo dissociation in presence of alkali $(>12.5 \mathrm{pH})$ to form $\mathrm{H}_{2} \mathrm{IO}_{6}{ }^{3-}$.

- Osmium(VI) reacts with $\mathrm{H}_{2} \mathrm{IO}_{6}{ }^{3-}$ to form an $\operatorname{adduct}\left(\mathrm{X}_{1}\right)$

- This adduct further reacts with another molecule of $\mathrm{H}_{2} \mathrm{IO}_{6}{ }^{3-}$ in a fast step to form $\mathrm{X}_{2}$.

- Subsequently $\mathrm{X}_{2}$ decomposes in a slow step to give osmium(VIII) and I(VI).

- $\mathrm{I}(\mathrm{VI})$ then reacts with arginine in a fast step to form arginine ketoacid and $\mathrm{I}(\mathrm{V})$.

Intimate mechanism

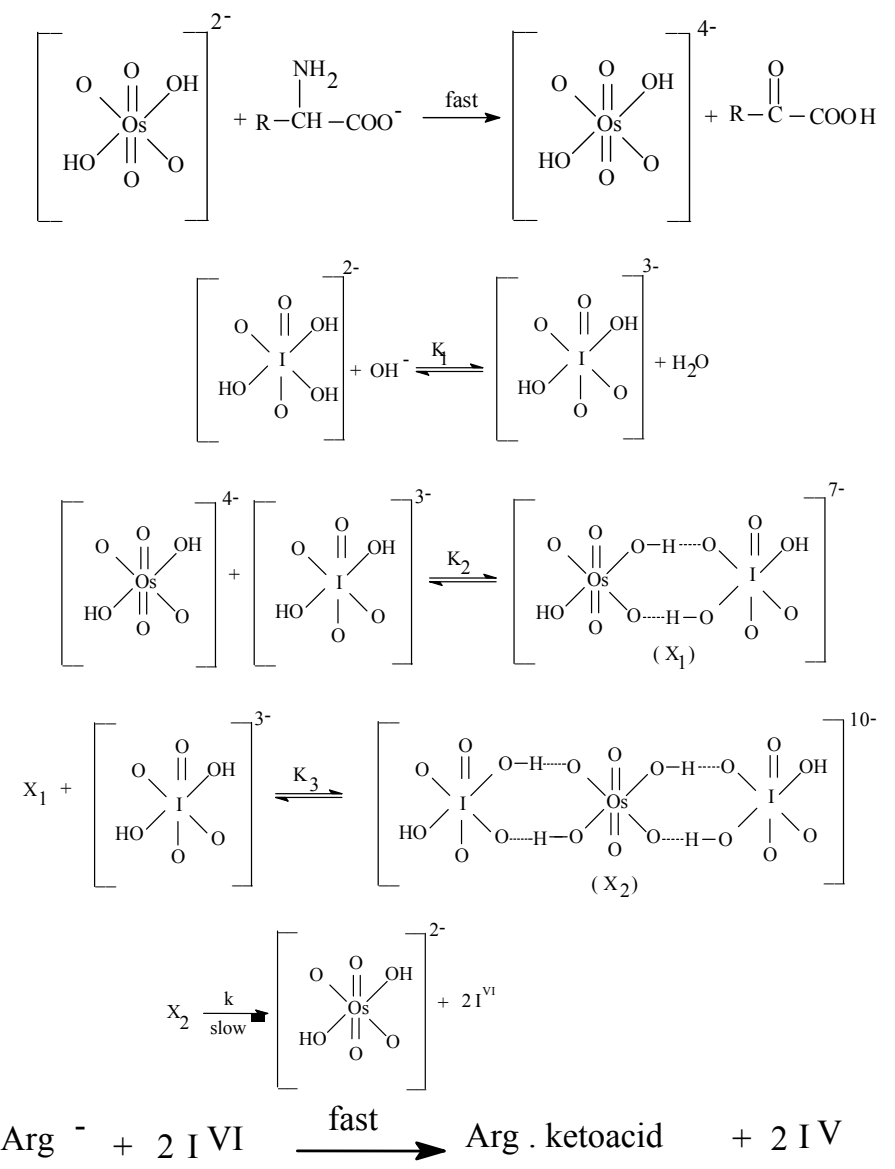

\section{References}

1. Mahadevappa D S, Rangappa K S and Gowda N M M, Reac Kinet Catal Lett., 1980, 15(1), 13-19; DOI:10.1007/BF02062378

2. Mahadevappa D S, Rangappa K S, Gowda N M M and Gowda B T, Int J Chem Kinet., 1982, 14(11), 1183-1197; DOI:10.1002/kin.550141103

3. Gowda B T and Rao R V L, Indian J Chem., 1985, 29A, 1021-1024. 
4. Mahanthi M K and Laloo D, J Chem Soc Dalton Trans., 1990, 311-313.

5. Panari R G, Chougale R B and Nandibewoor S T, Oxid Commun., 1998, 21, 503-512.

6. Kembhavi M R, Harihar A L and Nandibewoor S T, J Indian Chem Soc., 1999, 76, 79-82.

7. Harihar A L, Kembhavi M R and Nandibewoor S T, J Indian Chem Soc., 1999, 76, 128-130.

8. Chandraju S and Rangappa K S, Oxid Commun., 1999, 22, 448-457.

9. Chandraju S, Sherigara B S and Gowda N M M, Int J Chem Kinet., 1994, 26(11), 1105-1119; DOI:10.1002/kin.550261106

10. Sunil D and Archana P, Oxid Commun., 2000, 23, 451-458.

11. Sunil D and Archana P, Bull Pol Acad Sci Chem., 2001, 49, 183-191.

12. Nirmala H, Desai N, Saleem M and Nandibewoor S T, Tran Met Chem., 2001, 26(1-2), 28-35; DOI:10.1023/A:100719530425

13. Vivekanandan K, Oxid Commun., 2004, 27(1), 195-202.

14. Mohamed F N A, Prabaharan R, Rahini S, Kumar R S, Rajamahendran G and Krishnan B G, J Chem., 2004, 1(2), 127-131; DOI:10.1155/2004/406567

15. Sridevi G, Annapurna N and Vani P, J Indian Chem Soc., 2010, 87, 773-778.

16. Sridevi G and Vani P, Res J Pharma, Biolog Chem Sci., 2010, 1(4), 977-986.

17. Hiremath G A, Timmanagoudar P L, Chougale R B and Nandibewoor S T, $J$ Indian Chem Soc., 1998, 75(6), 363-367.

18. Sridevi N, Rambabu R and Dikshitulu L S A, J Indian Chem Soc., 1990, 67(7), 552-554. 